\title{
Tax Benefits For Education Part Two
}

Raj Kiani, (E-mail: rkiani@csun.edu), California State University, Northridge

Gary Stout, (E-mail: gary.stout@csun.edu), California State University, Northridge

\begin{abstract}
The past ten years have been a time of great change in the tax treatment of education expenses. Part I of this research covered the HOPE Scholarship, Lifetime Learning Credits, deductibility of student loan interest, eligibility for tuition deduction, and comparison of credits versus deductions. This article (Part II) provides an overview of Qualified Tuition Programs which are referred to as Sec. 529 plans. These plans were authorized by Congress in 1996 and expanded in 2001. These taxadvantaged savings benefits were set to expire on December 31, 2010. However, Section 1304 in title XIII of the Pension Protection Act of 2006 approved by Congress permanently eliminated the "sunset" provision, thereby making Section 529 plans permanent. This article provides an overview of Section 529 plans as well as Coverdell Education Savings Accounts which are, in essence, IRAs established exclusively for the purpose of paying qualified educational expenses.
\end{abstract}

\section{INTRODUCTION}

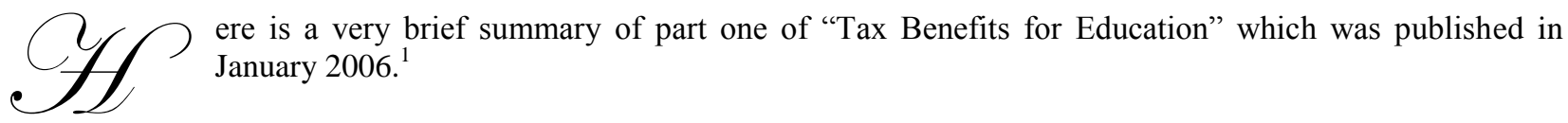

The past nine years have been times of great change in the tax treatment of higher education expenses. The Taxpayer Relief Act of 1997 started this process with the creation of the HOPE Scholarship and Lifetime Learning Credits. The subsequent

Economic Growth and Tax Relief Reconciliation Act of 2001 expanded these incentives. In part one of the research we have provided an overview of determining eligibility for education credits such as The HOPE Scholarship and Lifetime Learning Credits and computation thereof, discussion of the deductibility of student loan interest, eligibility for tuition and education fees deduction, and comparison of credits versus deductions in terms of which one is more beneficial to a particular taxpayer.

In this paper we focus on Section 529 plans and Coverdell Education Savings Accounts (ESA).The main objectives are: To explain (a) each plan (program) and how it works; (b) provide advantages and disadvantages of each plan; (c) compare the two plans; and finally, (d) to make recommendations concerning which one of these plans is more beneficial to a particular account holder.

Section 529 plans were authorized by Congress in 1996. These plans are officially known as qualified tuition programs (QTPs). ${ }^{2}$ There are two types of Section 529 plans: (a) College Savings Plans, and (b) Pre-paid Tuition Plans. Every State in the Union and the District of Columbia has at least one of these two options and many States offer both. The subsequent Economic Growth and Tax Relief Reconciliation Act of 2001 made 529 plans even more appealing, beginning in January 2002. These tax-advantaged savings benefits were set to expire on December 31, 2010. However, Section 1304 in title XIII of the Pension Protection Act of 2006 approved by Congress permanently eliminated the "sunset" provision, thereby making Section 529 plans permanent.

\footnotetext{
${ }^{1}$ R.Kiani,G. Stout, Tax Benefits for Education, Journal of Business \& Economics Research, Jan .2006

2. These plans are commonly referred to as "529 plans", "State 529 plans," or "Section 529 plans" after the section of the IRS Code that provides the plans' special tax breaks.
} 


\section{WHAT IS A 529 PLAN?}

We quite often tell our children and/or grand children "you can be anything you want to be." So how can we help them become all they can become? Just remember, tomorrow will be here sooner than you think. Therefore, you should formulate a long term strategic plan as soon as possible by starting an investment program for them today, so you put time (and compound interest) on your side.

A Section 529 plan is a college savings plan designed to systematically help you build funds for your children's and /or grandchildren's college costs. There are two types of 529 plans:

- $\quad$ Pre-paid tuition plans and

- $\quad$ College savings plans.

Pre-paid tuition plans generally allow you to buy college units or credits at participating universities and colleges for future tuition. However, most pre-paid tuition plans are sponsored by state governments and have residency requirements. Many state governments guarantee investments in pre-paid tuition plans that they sponsor. Most pre-paid plans set lump sum and installment payment prices prior to purchase, based on age of beneficiary and number of years of college tuition purchased.

Under college savings plans a college saver (which is known as "account holder") ${ }^{3}$ generally has permission to establish an account for a student (the "beneficiary") ${ }^{4}$ for the purpose of paying the beneficiary's eligible college expenses. College savings plans cover all "qualified higher education expenses," including: tuition, room \& board, mandatory fees, and books, as well as, computer (if required). The account holder must be either a natural person of legal age or certain other legal entities with the authority to establish an account for the designated beneficiary. Furthermore, the account holder maintains control over the account and is responsible for directing any withdrawals. The designated beneficiary has no control over the assets of the account and may not direct withdrawals from the account.

The custodian for a minor under a state's Uniform Gifts to Minors Act or Uniform Transfers to Minors Act ("UGMA/UTMA") may establish an account that is subject to additional limitations, such as the inability to change the designated beneficiary and certain restrictions on withdrawals which is depends on the laws of that state. Therefore, we highly recommend that a custodian should consult his or her tax advisor for additional information concerning these restrictions before opening an account.

In general, UGMA/UTMA custodial accounts are subject to additional requirements and restrictions:

- $\quad$ The UGMA/UTMA custodian will be permitted to make withdrawals only in accordance with the rules applicable under UGMA/UTMA and the Program(plan);

- $\quad$ The custodian will not be able to change the designated beneficiary of the account (directly or by means of a rollover distribution), except as may be permitted by applicable UGMA/UTMA law;

- The custodian will not be permitted to change the account holder to anyone other than a successor custodian during the term of the custodial account under applicable UGMA/UTMA law.

The account holder of a 529 plan may typically choose among several investment options for his or her contributions, which the college savings plan invests on behalf of the account holder. Investment options often include stock mutual funds, bond mutual funds, and money market funds and etc. Withdrawals from college savings plans can generally be used at any college or university. Lifetime contribution limits to each type of plan can vary between $\$ 220,000$ and $\$ 277,000$ depending upon State tax treatment which varies by state. You should consult with your tax

\footnotetext{
${ }^{3}$ The account holder (owner) should consult with his or her financial and tax advisor, before opening an account for the designated beneficiary.

${ }^{4}$ IRS Publication 970, 2005. A designated beneficiary is a member of the family which is defined as: father, mother, son, daughter, stepfather or step mother, stepson or stepdaughter, brother, sister, stepbrother or stepsister.etc, and finally first cousin.
} 
advisor about any state or local taxes before making any tax-related decisions. Investments in college savings plans that invest in mutual funds are not guaranteed by state governments and are not federally insured.

When you invest in a 529 college savings plans, you are not only giving the people you care about a chance to get the best education possible, you are also providing yourself with a tax-advantaged way to save. While parents are generally on the front lines when it comes to funding college; however, quite often grandparents can use special gift tax treatment to become involved in creating a multi-generational approach that will insure college investing goals will be met for all family members. The grandparents' annual contributions to a 529 plan qualify for the annual gift tax exclusion. Therefore, they may be able to reduce the tax burden on their heirs by reducing the size of their estate. The grandparents can contribute up to $\$ 12,000$ per beneficiary annually ( $\$ 24,000$ if a couple) without incurring federal gift taxes. Or, according to a special forward -gifting provision, they can choose to make a one-time gift up to $\$ 60,000$ per beneficiary ( $\$ 120,000$ if they're married), provided there are no further gifts to that beneficiary in the same five-year period. They also have the option to make their contributions to an account maintained by a grandchild's parent and still take advantage of the gift-tax exclusion. Of course, they should consult their tax and estate advisors before taking this action.

\section{WHY 529 PLANS MAKES SENSE}

Here are some of the reasons why you should consider a 529 account:

- $\quad$ You can use the funds at virtually any accredited school in the country.

- $\quad$ It may offer you considerable savings on income and estate taxes.

- $\quad$ There are no limitations on who can open an account.

- $\quad$ Anyone can invest - whether or not they're related to the beneficiary.

- $\quad$ Assets can be used to pay for tuition, fees, and other qualified expenses.

- $\quad$ The account holder (owner) controls the assets of the plan, not the beneficiary.

- You can make a maximum contribution of up to $\$ 277,000$. State tax treatment varies by state. The maximum allowable contribution limit is based on the aggregate market value of the account(s) for a designated beneficiary, not on the aggregate contributions made to accounts. Accounts that have reached the maximum allowable contribution limit may continue to increase in value due to market fluctuation and compounding.

The advantages of college savings plans are:

- Withdrawals for educational expenses are federal tax-free;

- $\quad$ you can switch investment options within the same plan once per year;

- $\quad$ you can roll over one 529 plan into another once per year;

- you can contribute to Coverdell Education Savings Accounts (formerly Education IRA) and 529 plans in the same year; and

- $\quad$ you can switch beneficiaries to certain relatives. ${ }^{5}$

\section{COVERDELL EDUCATION SAVINGS ACCOUNT (ESA)}

A Coverdell ESA is a savings account that is established for the exclusive purpose of paying the qualified education expenses such as elementary, secondary and higher education of a designated beneficiary. This is a trust or custodial account that must be created in the United States at any bank or other IRS approved organization that offers Coverdell ESAs. ${ }^{6}$

\footnotetext{
${ }^{5}$ IRS Publication 970, 2005

${ }^{6}$ IRS Code Sections 530(b)(1) \& 530(b)(2)
} 


\section{REQUIREMENTS OF A COVERDELL ESA}

- When the account is created, the designated beneficiary must be under age 18 or a special needs beneficiary. Therefore, no Coverdell ESA contribution can be made to a designated beneficiary after he or she reaches age 18. In addition, the assets of the Coverdell ESA must be distributed to the designated beneficiary within 30 days of the designated beneficiary's reached of age 30 and /or the beneficiary's death. ${ }^{7}$

- $\quad$ The trustee or custodian must be a bank or an entity approved by the IRS.

- A Coverdell ESA contribution must be in cash. The contribution must be made by the due date of the contributor's tax return (not including extensions). Moreover; the maximum amount of contribution to any and all Coverdell ESAs on behalf of a designated beneficiary is \$2,000 per year. After 2010 this limit will revert to $\$ 500$ per year. These annual limits are further reduced (or eliminated) based upon the depositor's modified adjusted gross income (MAGI). For joint returns the limitation applies between $\$ 190,000$ and $\$ 220,000$ and for single taxpayers the limitation applies between $\$ 95,000$ and $\$ 110,000$. However, the designated beneficiary may contribute to his or her own Coverdell ESA.

- $\quad$ The assets of Coverdell ESA can not be commingled with other property nor be invested in life insurance contracts. $^{8}$

\section{TAX CONSEQUENCES OF ESTABLISHING A COVERDELL ESA}

In brief, some of the tax consequences of establishing a Coverdell ESA are as follows:

- $\quad$ Contributions to Coverdell ESAs (including transfers and rollovers) ${ }^{9}$ are not tax deductible. However, the investment earnings of the Coverdell ESA are not subject to federal income tax as accumulated in the Coverdell ESA.

- $\quad$ A distribution from a Coverdell ESA used to pay for a designated beneficiary's elementary, secondary or postsecondary qualified education expenses at an eligible institution are tax free. But, a portion of the distribution is generally taxable to the designated beneficiary if the distributions are more than beneficiary's qualified education expenses for the year. Furthermore, in most cases of a nonqualified distribution, the taxable portion of a Coverdell ESA is also subject to an additional $10 \%$ penalty. Withdrawals from the Coverdell ESAs are not subject to federal income tax withholding. ${ }^{10}$

- The Coverdell ESA will lose its tax-exempt status completely if the responsible individual engages in a prohibited transaction. ${ }^{11}$ If so, the designated beneficiary must report the value of earnings in the account in his or her gross income for the year.

\section{SUMMARY AND CONCLUSIONS:}

College investing programs come in many shapes and sizes today. That is why strategic planning and critical thinking is very essential as to how and when such investments are to be considered. As a result, one can choose the right college plan which best fit their needs and therefore capitalize on the investment opportunities for their children's higher education. The following chart is a summary which will help to compare the various alternatives and make sound and educated decisions as to the best way to invest and get the most tax benefits for their children's future education.

\footnotetext{
${ }^{7}$ IRS Publication 970, 2005

${ }^{8}$ IRS Publication 970, 2005

${ }^{9}$ IR S Code Section 530(d) (5). Funds distributed from a Coverdell ESA may be rolled over to another Coverdell ESA of the same beneficiary or that of a qualified family member as long as the requirements of IRC Section 530(d)(5).Qualified family member include the beneficiary's spouse, child, grandchild, sister, brother, parent, niece or nephew, son-in -law, daughter-in-law, brotherin-law, sister-in-law, and so on.

${ }^{10}$ IRS Publication 970, 2005

${ }^{11}$ James E. Smith, West Federal Taxation, 2004 Ed.(Thomson/South-Western Publishing Co. 2004), IRC Section 4975
} 
Summary of investment options for making comparison and then choosing the best way to invest for a child future higher education expenses

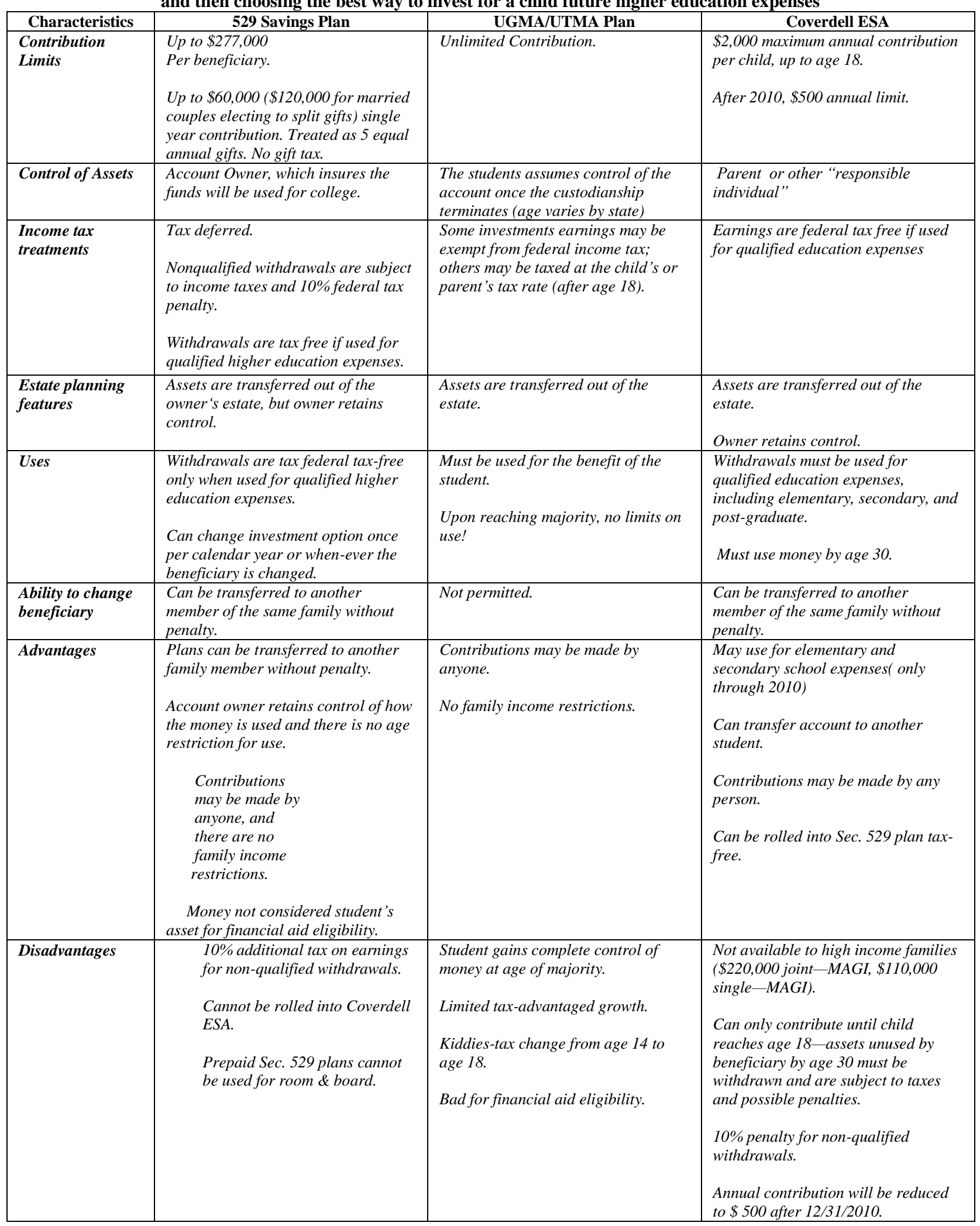




\section{REFERENCES}

1. Kiani. R., Stout. G., Tax Benefits for Education, Journal of Business \& Economics Research, Jan. 2006)

2. IRS Publication 970, Tax Benefits for Higher Education, 2005

3. $\quad$ IRS Code Sections 530(b)(1) \& 530 (b)92), 530(d)(5)

4. IRS Section 4975.

5. James E. Smith, West Federal Taxation, 2005 Ed. ( Thomson/South -West Pub. Co.2005)

\section{NOTES}

